\title{
Interactive comment on "Implementing a hydrodynamic model to complement water depth and flow velocity data for physical scale experiments of rivers and estuaries" by Steven A. H. Weisscher et al.
}

Steven A. H. Weisscher et al.

s.a.h.weisscher@uu.nl

Received and published: 29 June 2020

Please find enclosed in the pdf supplement our response to the first reviewer. We describe in blue how we will use the reviewer comments to improve the manuscript.

Please also note the supplement to this comment: 
Interactive comment on Earth Surf. Dynam. Discuss., https://doi.org/10.5194/esurf-2020-14, 2020.
ESurfD

Interactive comment 